\title{
IMPACTS OF SOCIAL CAPITAL ON TRANSFORMATION FROM EFFICIENCY TO INNOVATION-DRIVEN BUSINESS
}

\author{
Mindaugas LAUŽIKAS ${ }^{1}$, Simona DAILYDAITÉ ${ }^{2}$ \\ ISC Paris Business School (Institut supérieur du commerce de Paris), 22, \\ bd du Fort de Vaux, 75017 Paris, France \\ E-mails: ${ }^{1}$ mindaugas.lauzikas@gmail.com (corresponding author); \\ ${ }^{2}$ simona.dailydaite@gmail.com
}

Received 17 August 2012; accepted 27 November 2012

\begin{abstract}
The present article is focused on impacts of social capital on transformation from efficiency to innovation-driven business. Such aspects of social capital as social relations, usage of human capital in innovation processes, expertise in market analysis are often ignored by entrepreneurs. The research purpose is to analyse the relation between social capital and transformation from efficiency to innovation-driven business. Main aspects of this relation are revealed by interpreting findings of Global Entrepreneurship Monitor (GEM), which is to examine how different factors encourage economic development globally via entrepreneurship. Relying on a solid GEM methodology, which combines quantitative adult survey and qualitative expert interviews, various transformation problems of catching-up countries are analysed while paying a special attention to effects of social capital and illustrating them by the case of Lithuania. The role of human capital is measured by such factors as anticipated growth of headcount within respondents' firms; social relations refer to social image of entrepreneurs (as it is impossible to have a strong social image without good social relations with stakeholders), while information/ knowledge diffusion is analysed via such effects as a number of companies that deliver innovative products and/or services, a number of customers who appreciate and want to try innovative products and/or services as well as a number of expected competitors in the market (it is impossible to be innovative and competitive in the market without information/feedback collection system established).
\end{abstract}

Keywords: social capital, social norms, social networks, economic growth, innovation, entrepreneurship, organizational culture.

JEL Classification: A13, D22, D83, L14, L26, M21.

\section{Introduction}

The present article aims to tackle arguments presented in two groups of scientific literature sources. One group is related to social capital and its effects on the economy, and another group of sources refers to the transformation of economy from efficiency to innovation-driven stage. The analysis of the role of social capital on economic development should be started by quoting Putnam's (1993a) definition of social capital, 
where social capital captures features of social organizations, such as networks, norms and trust that facilitate co-ordination and co-operation for mutual benefit. The concept of social capital, its main dimensions and impacts on the economy were later well-discussed by such authors as McKeever et al. (2014), Lin (2000), Adler and Kwon (2002), Landry et al. (2002), De Clercq and Dakhli (2004), Durlauf and Fafchamps (2005), Yu (2013), Lee et al. (2005), Doh and Acs (2010), and etc. Transformation from efficiency to innovation-driven stage is scrutinized by interpreting arguments of Lundvall et al. (1994), Porter (2003), Hjerppe (2003), Nielsen (2005), Callois and Schmitt (2005), Kaasa and Parts (2008), Dasgupta (2009), Acs and Szerb (2010), Global Entrepreneurship Monitoring (2012) and others that are well presented in further chapters of the present publication.

Global Entrepreneurship Monitor (2012) reveals the existence of different stages of economy development. This paper encompasses aspects of transformation from efficiency to innovation-driven business. Within the creation process companies often do not have enough information about such important aspects of business as prices, production processes, costs and competition. This type of information is usually widely scattered among market participants (customers, suppliers, etc.) and indirect market participants. Thus, more profound market knowledge could lead to: the identification of all stakeholders, key-strategic relationships, and ways they can affect companies' performance (including potential synergies); strengthening feedback collection capabilities; finding right information/ knowledge diffusion channels. All these aspects help entrepreneurs to get necessary information and turn it into innovations. It is argued that human capital variables (for instance, entrepreneurial and leadership experience or human resource strategies) have a positive and important impact on start-up companies and their development (Cantner, Stützer 2010). Landry et al. (2000) add that firms with a large stock of social capital always have a competitive advantage of reliable information. Thus, social capital acts as a key element of transformation from efficiency to innovation-driven business by creating competitive advantages for organizations.

\section{Methodology}

Investigation of impacts of social capital on transformation from efficiency-driven to innovation-driven stage is continued by the presentation of the Global Entrepreneurship Monitor methodology. The present article supports important aspects of the research problem by the data for the year of 2011 from GEM, which is the largest dataset on entrepreneurship worldwide. GEM is a non-profit academic research consortium, started in 1998, which estimates the participation in business start-ups and new firms in different countries. From 10 countries in 1998 it grew to 86 economies overall in 2011. Lithuanian Entrepreneurship Monitor is the part of global GEM. According to the GEM methodology, two research methods are used: the quantitative adult survey (APS: Adult Population Survey) and qualitative interviews with experts (NES: National Experts Survey).

The APS investigates the role of an individual in the life-cycle of the entrepreneurial process, and his or her characteristics or actions. The APS is unique because it stud- 
ies entrepreneurship through adults' motives and attitudes as they strive to set up, to start and maintain businesses. The sample sizes vary by nation; however, the minimum APS sample size equals 2000. The APS is comprised of modules of different groups of questions: core APS questions (mandatory), special topics (for instance, immigration, inter firm networks: mandatory), innovation questions (optional), network question (optional). The blocks include such types of respondents as nascent-entrepreneurs, owners-managers, potential and discontinuing entrepreneurs, informal investors, while demographics are compulsory to all respondents.

The NES is a survey personally conducted by each of GEM participating teams. The purpose of NES is to get the information on average state of institutions and framework conditions to develop entrepreneurial activities in a concrete territory. Any NES sample must include 36 experts (it can include more but no less). This number is justified because it is needed (at least) 4 experts by each of 9 critical conditions before presented to get a reasonable statistical reliability (GEM 2012). The corresponding GEM team must select 4 experts for each group (at least 1 in each group must be an entrepreneur or consolidated business person: financing, government policies, governmental programs, education, R\&D transfer, commercial and business services, internal market openness, physical infrastructure, social and cultural norms).

Countries are divided into three groups: factors-driven, efficiency-driven and innovation-oriented. Although these categories are related to countries, the fact that companies, particularly small and medium ones, are the driving force of economies should be taken into consideration.

On the side of main elements of social capital in Lithuania such aspects of social capital as social and interpersonal relations, strategic development of a company (with an efficient use of all available resources), human (as well as intellectual) capital development, information and knowledge management (particularly the access to information and its diffusion), good relations with all stakeholders given a focus on consumers' needs and expectations as well as a good expertise in market analysis (while relying on the feedback from various stakeholders) should be examined.

The Lithuanian survey of experts Laužikas et al. was conducted in September 2011. Based on the GEM methodology there were 36 entrepreneurship-related experts from 9 critical groups interviewed (4 experts from each group: financing, government policies, governmental programs, education, R\&D transfer, commercial and business services, internal market openness, physical infrastructure, social and cultural norms). The research was carried out by the Lithuanian team of Global Entrepreneurship Monitor. In addition to a regular GEM questionnaire an extra group of questions on social image of entrepreneurs was carried out. There were three main groups of factors influencing the social image of entrepreneurs underlined: human attitudes towards entrepreneurial activities, social norms and support as well as human capabilities and skills to run entrepreneurial activities. It should be added that human attitudes regarding entrepreneurship are largely related to personal characteristics and education of entrepreneurs. People choose between two career alternatives: to be self-employed or to be employed by an employer. Their choice depends not only on the social image of entrepreneurs, 
but also on their characteristics. This refers to citizens' choice to be an entrepreneur or an intrapreneur, or to be involved in both activities.

While conducting the quantitative adult survey in total there were 2003 Lithuanian adults (respondents) from 18 to 64 years interrogated. The regional distribution of respondents corresponded proportions of a regional spread at the county's level and ensured the representativeness and confidence of research results.

\section{Concept of social capital}

Grootaert (1998) claims, that social capital encompasses norms, networks and organizations where individuals have access to the power and resources. Social capital also refers to the relationship among individuals. Such problems as communication, trust and mutuality of relationship are concepts of social capital (Pohja 2009). According to Colesca (2009), trust is just an abstract concept related to the whole of relationship. Furthermore, some authors emphasize the role of media in encouraging entrepreneurship in the society via transmission of entrepreneurship-related values and images (Hang, Van Weezel 2005). Also, social capital has different forms and scopes where not only the media, but also other subjects can make an influence on entrepreneurship (Fig. 1).

The meso-level social capital refers to communities and associational organizations. The Macro level covers the governance and institutions of state, whereas the Micro level involves local institutions, networks and local norms, trust and values. The structural dimension is a concept, which describes relationship among people in networks (Johnson et al. 2002). Inkpen and Tsang (2005), referring to Gulati et al. (2000), describe the cognitive dimension as expressing a common understanding and purposes among members and generate appropriate behaviour norms.

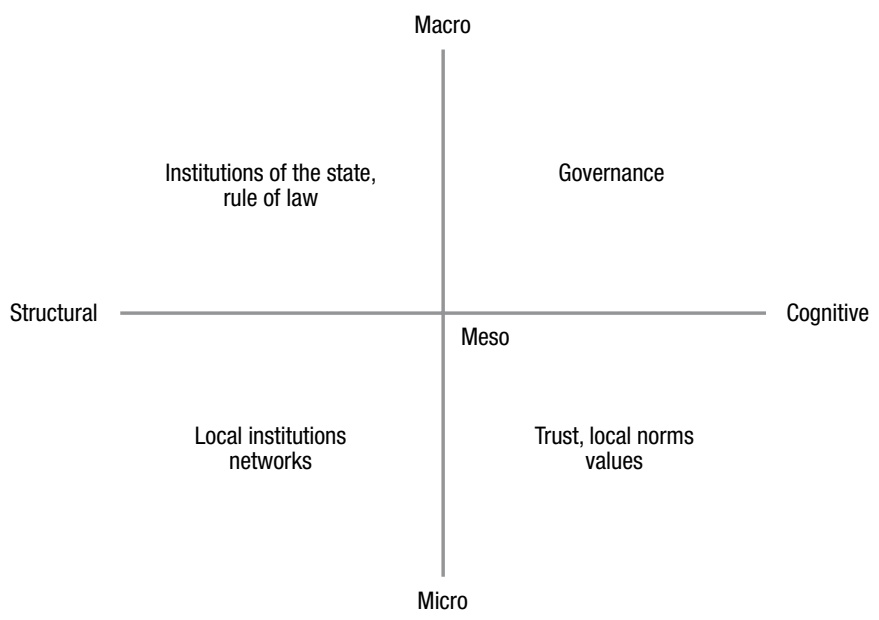

Fig. 1. The forms and scope of social capital Source: Grootaert, Van Bastelaer (2002: 4). 
On the other hand, based on Coleman (1988) insights, social capital creates human capital in the next generation. It could be understood as an indirect relation between social capital and innovation, which employs human capital at the organizational level.

Social networks could be both an important factor for entrepreneurship (McKeever et al. 2014) and a result. It could be analysed as a key factor in the concept of social capital, because network diversity is related to innovation of enterprises ( $\mathrm{Yu} 2013$ ). The ties in social networks give access to resources for companies that provide not only a wide range of opportunities, but also a number of constraints (Johnson et al. 2002).

Moreover, it is highlighted that if people trust in others, it is likely that they have a strong moral and standards of honest behaviour (Uslaner 1999). Cantner and Stützer (2010) admit that the combined effect of human and social capital enhances opportunities for survival of a new enterprise. Drawing on the work of Übius et al. (2013), the organisation climate acts as a key element of innovation for an organization. At the organizational level innovations are closely related to job satisfaction, which could be defined as a part of social capital.

In general, it means that social capital acts as a factor which contributes to economic development; in parallel, it acts as the driving factor for innovation capabilities (Laužikas, Dailydaite 2012). As a result, social capital has a huge impact on transformation from efficiency to innovation driven business.

\section{Entrepreneurship stages of economic development}

Acs and Szerb (2010), based on the Porter's (2003) tradition, state that the development of innovations in the economy is closely linked with entrepreneurship. Porter created three stages of development that helped to understand the contemporary approach to entrepreneurship. The first stage is factors-driven. This stage refers to a big number of people, self-employed in the agricultural sector. At this stage, countries compete with a cheap labour force, manufacturing low value-added products, and individual enterprises dominate in the manufacturing or service sector. Before moving to the second stage, which is based on the efficiency, states must increase efficiency and productivity and train the workforce to be able to adapt to the technological development (Acs, Autio 2011). Such countries as Pakistan, Bangladesh, Iran, Algeria, Jamaica, Venezuela and Guatemala belong to the factors-driven stage (Global Entrepreneurship Monitor 2011).

Countries wishing to compete in the efficiency-driven stage must have efficient production practices in large markets that allow companies to realize the "mass production". Producers who supply daily-use goods and services dominate. It is emphasized that this stage encloses a smaller percentage of people who are self-employed, and the labour force as well as the capital play one of the essential roles determining the productivity. These countries focus on technologies (Acs, Szerb 2010). According to the Global Entrepreneurship Monitoring (2011) report, Malaysia, Russia, Poland, Bosnia and Herzegovina, South Africa, Turkey, Lithuania, Romania, Slovakia, Latvia, Mexico, Brazil, Argentina, Peru, Thailand, China, Croatia, Hungary and many others belong to 
this stage (Global Entrepreneurship Monitor 2011). One of the main disadvantages of this stage, compared to the innovation-driven one, is that the level of education and the business efficiency is lower (Harris 2010).

The innovation-driven economies are those where the main tool is the knowledge helping to create innovative products/services using technologies at the global level, and, as a result, companies have their competitive advantages (Porter 2003). Wennekers et al. (2009) indicate that this stage is characterized by a high level of income per capita. Moving to this stage requires not only developing the ability to generate new knowledge, but also the demand for commercialization. This leads to intensive cooperation among universities, businesses and governments. This stage encompasses the strongest countries in the world: Slovenia, Denmark, France, Japan, Korea, Ireland, Norway, Czech Republic, Finland, United Arab Emirates, Germany, Sweden, Belgium, Spain, United Kingdom, Greece, Netherlands, Switzerland, Singapore, Australia, United States, and etc. (Global Entrepreneurship Monitor 2011).

\section{The economic efficiency via social capital dimension}

In a similar way as Cipolla (1981) and Lazonick (1991), Wong et al. (2005) describe the economic history until the twentieth century by explaining that entrepreneurship is a critical factor in a long-term economic growth. Wong et al. rely on Weiss' (1976) ideas that entrepreneurs apply new technologies, redistribute resources for new opportunities, diversify production and create competitive conditions entering new markets. In accordance with Jovanovic (1982) and Audretsch (1995), theoretical links of entrepreneurship and growth led to new theories, derived from the industrial evolution and economic changes. It is stated that entrepreneurs act as a catalyst for changes bringing new ideas to the market. Scientists focus on the impact of social capital on economic growth (Dasgupta 2009; Kaasa, Parts 2008; Hjerppe 2003; Callois, Schmitt 2005; Musai et al. 2011). "At the microeconomic level this is seen primarily through ways the social capital improves functioning of markets. At the macroeconomic level, institutions, legal frameworks, as well as the governmental role on the production organization are seen as affecting the macroeconomic performance" (Grootaert 1998: 2). Hjerppe (2003) agrees that the relation among social capital, government and economic growth exists.

Relying on Lundvall et al. (1994), Nielsen (2005) points out, that technological, social, economic and cultural aspects play the essential role in explaining dynamics of modern innovation processes. Human capital can be understood not only as intellectual capital (Serrat 2011), but also as a concept of social capital (Coleman 1988; Putnam 1993b). It should be noted that human capital is a key factor for development of innovations in organizations. Nahapiet and Ghoshal (1989) note that social capital is influential in the development of new intellectual capital, and that organizations are institutional settings conducive to the development of social capital.

According to Cantner and Stützer (2010), benefits of social capital are related to the access to a relevant and innovative information. In addition, there should be benefits 
of networks for innovative activities, facilitating the access to broader sources of information, scrutinized. Camps and Marquès (2011), based on Nahapiet and Ghoshal (1998), suppose that structural dimension makes the influence on communication and information flow within organizations. Thus, social capital in the structural dimension context creates the added-value for organizations as well as for an economy, facilitating the access to broader sources of information and improving the information quality, relevance and timeliness. Özdemir and Demirci (2012) emphasize the Cooper's (1999) argumentation where the experience of members is a factor of success in innovative activities as well as new and creative ideas. It is accepted as an integral part of innovation progress. Stam and Elfring (2008) rely on Teece's (1986) ideas where informal industry networks are considered a source of social capital for entrepreneurs.

Yusof and Abidin (2011), based on Valencia et al. (2010), indicate that the organizational culture can act as a driving factor or as a barrier for innovations. Organizational culture and dimensions of the organizational climate are related to the creativity and innovations. Cantner and Stützer (2010), relying on Aldrich's et al. (2001) ideas, note that the access to resources is critically important to small and young companies in innovative industries (including financial capital, skilled workforce or necessary equipment for R\&D and production).

While interpreting Bueno's et al. (2004) and Sabatini’s (2006) arguments Mačerinskienè and Aleknavičiūte (2011) note, that social capital can improve economic capabilities of consumers and producers, to make the influence on relations with suppliers, as well as to promote the inter-organizational learning. It is emphasized that social capital creates intellectual capital and increases efficiency of multidisciplinary teams in enterprises; it helps to reduce rotation of employees and stimulates innovations. One of the main factors acting as a driving factor for an economy is that social capital facilitates exchange of resources and helps to reduce the average cost of transactions.

\section{Conditions for a successful transformation to innovation-driven stage: the case of Lithuania}

Driven by the fact that social capital encloses social relations in an economy and all relationship-related consequences, such as confidence among stockholders, attitudes or willingness to support, social relations could bring such effect as social image of entrepreneurs. While strengthening the Lithuanian national innovation system it is important that $40 \%$ of respondents consider entrepreneurs innovative: not only because entrepreneurs show positive examples to the population by introducing new products and/or services to the market, but also because of generating higher added-value to the economy. Based on experts' opinion, social image of entrepreneurs is positive in Lithuania. Experts believe that successful businessmen are related to a high status in the society, and their career is an attractive choice. However, experts are less willing to agree that entrepreneurs are able to manage resources, which could be a signal that their chosen strategies are not in favour of transformation to innovation-driven stage.

Another social capital dimension which is examined is information/knowledge diffusion. Information/knowledge diffusion is analysed in terms of information/feedback 
collection and is examined via such effects as a number of companies that deliver innovative products and/or services, a number of customers who appreciate and want to try innovative products and/or services as well a number of expected competitors in the market. The companies' choices and actions are unlikely to be in line with customers' needs without a proper information/feedback collection model established. Having no profound information/feedback collection model, companies more than customers appreciate innovations, but less than customers try them, which is often the illustration of the lack of orientation of innovation strategy to consumers' needs. Most of experts $(64 \%)$ agree with the fact that customers try new products and/or services; however, respondents are not so optimistic. While answering to the question which part of potential customers (all, some, no one) will consider their products and/or services innovative more than half $(54.8 \%)$ of respondents who are starting or helping to start businesses expect their customers to have a negative opinion about the innovativeness of products and/or services delivered by their companies. Such results are even more demanding taking into consideration that $52.8 \%$ of respondents involved in businesses feel a severe competition in the market. A similar situation is among respondents who have already established their businesses (being owners and getting revenues): $71 \%$ of respondents believe that their products and/or services are not new to their customers/clients. On the one hand, this could be explained by incremental nature of Lithuanian innovations; on the other, it reveals the lack of orientation to consumers' needs. Results are aggravated by the fact that $66.7 \%$ of respondents feel a severe competition in the market.

It appears that at the beginning stage of their companies' development entrepreneurs do not orient activities to innovation processes and concentrate more on those fields where there are a lot of competitors with a vast range of products and/or services. Entering the saturated market entrepreneurs do not search for new niches abroad. It should be mentioned that targeted customers/clients of $69 \%$ of respondents (starting or helping to start businesses) will live in a local market (more than $90 \%$ of customers/clients will live in a local market). This could be explained by both the focus on establishing a stronger position in local market and a weakly-developed information/feedback collection system.

Based on GEM results for the year of 2011, within the efficiency-driven group total early-stage entrepreneurs (TEA) rates are not strongly related to innovation rates, as high innovation rates exist among countries with both high (Chile, Peru) and low (South Africa, Poland) TEA rates. Two different trends are also witnessed in innovation-driven countries. Denmark, having low TEA rates, shows the highest percentage of entrepreneurs with innovative products and services which could be linked to the quality dimension. On the contrary, innovation-driven economies with the highest TEA rates show moderate proportions of innovativeness, which could be the illustration of a trade-off between the quantity and quality dimensions. In addition, there are some common trends in terms of TEA and innovation rates in three groups of GEM countries: for instance, Lithuania (efficiency-driven country) is similar to Pakistan (factor-driven economy) and to such innovation-driven countries as Portugal, Finland, Belgium or Taiwan.

Driven by consideration of human capital as one of the most important elements of social capital (understood not only as an intellectual capital) and a key factor for devel- 
opment of innovations in organizations, the role of human capital development is measured by anticipated growth of headcount within respondents' firms. Managers should lead in transformation from efficiency-driven to innovation-driven stage and to strategically plan their human resource development. However, the expected number of people, excluding owners, in organizations and the dynamics of this percentage do not signify a great improvement in Lithuania. For instance, there are up to 3 employees (excluding owners) in companies of $57.9 \%$ business owners. Respondents expect to maintain similar proportions in the upcoming 5 years. In companies of $52.9 \%$ respondents there are more than 4 employees going to work, while $47.2 \%$ owners will employ up to 3 people. $71.3 \%$ of respondents believe that their executed activities should employ up to 20 people in the upcoming 5 years.

GEM analysis for the year of 2011 on growth expectations for 54 economies is made at three levels: 0-4 (low growth expectations), 5-19 (medium growth expectations) and 20 or more employees (high growth expectations). Factor-driven economies, in general, contain many entrepreneurs, but mostly in the low growth category. It should be added, that countries of different economic development stages can show similar percentages of entrepreneurs in different growth categories: for instance, Guatemala (factor-driven stage) and Peru (efficiency-driven stage) have similar percentages of entrepreneurs with 0-4 employee growth expectations, yet Peru has a substantial number of entrepreneurs at other two growth levels. Chile belongs to the efficiency-driven group of countries with a high level of moderate growth expectations and China is one of the leading countries, based on a relatively large part of entrepreneurs with high growth ambitions (GEM 2012). Lithuania falls into the group of such countries as Latvia, Turkey, Poland and Slovakia, all of them are efficiency-driven economies. Lithuania, Latvia and Turkey have more than half entrepreneurs with 5-19 or 20 and more jobs growth. Some countries of innovation-driven stage are more similar in terms of their proportions in different growth categories to efficiency-driven countries: for instance, there is a visible similarity between Taiwan and Lithuania. In spite of the fact that innovation-driven economies consistently report fewer entrepreneurs, a high proportion of growth ambitions in these economies shows that these fewer numbers of entrepreneurs contribute significantly to the employment growth.

To successfully transform to innovation-driven stage companies need to be involved in a continuous and sustainable development of innovations via an efficient usage of human resources as well as planning human resource development, which is a crucial part of social capital. In addition, managers need to feel well the situation in the rapidly transforming market and be flexible and fast in modifying their strategies, based on market needs. Feeling niches that could be profitable for their businesses is critical, however, it is impossible to achieve profits without confidence and trust among all stakeholders as well as having no efficient knowledge diffusion system established.

Although all three elements (orientation to product and/or service innovations; penetration of niche markets and attention to competitors; strategic human resource development) form the model of a successful transformation to the innovation driven stage (see the figure No. 2), Lithuanian companies do not pay a sufficient attention to these 


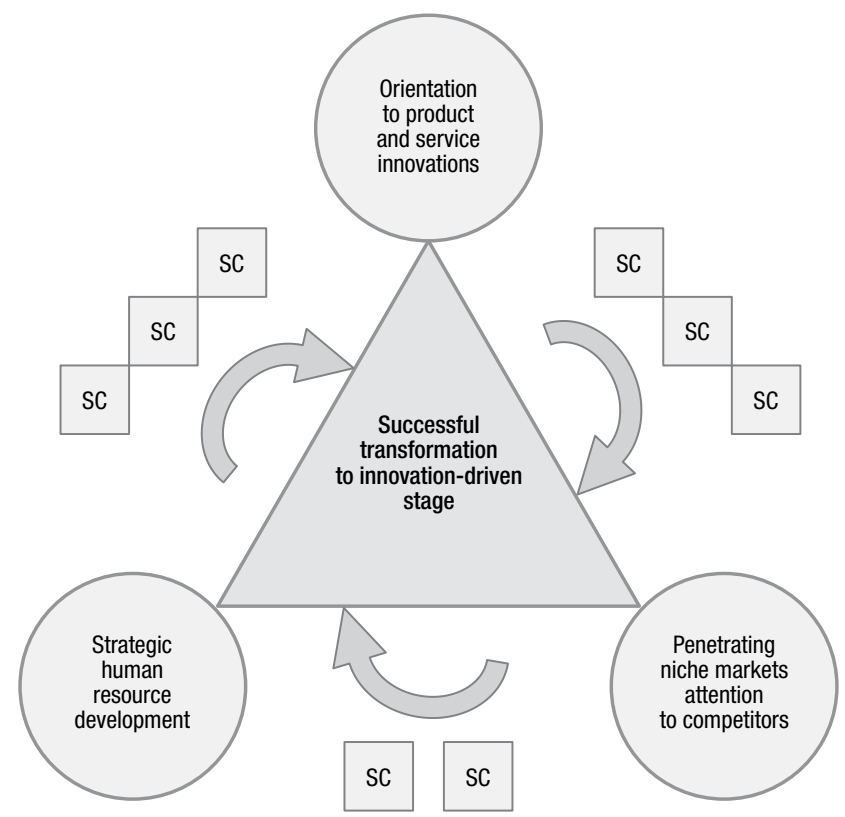

Fig. 2. Conditions for a successful transformation to the innovation-driven stage, SC refer to social capital

Source: prepared by authors, based on GEM, Lithuania (2012).

parameters. Entrepreneurs believe that their products and/or services will not be innovative; they are not searching niche markets and penetrating areas with a large number of competitors. More than that, they do not expect growth in headcount, which should be a precondition for continuous innovation development and growth.

\section{Conclusions}

The present article tackles effects of three social capital dimensions (social relations, human capital development and innovation/knowledge diffusion) on transformation from efficiency to innovation-driven business. It is one of the first scientific researches focused on identification and explanation of effects of social capital on innovativeness of business in efficiency-driven economies via using the globally-well known methodology of GEM and answering to the research question via both the case of one efficiencydriven economy (Lithuania) and conceptual model of conditions (created by authors) for a successful transformation to the innovation-driven stage. The scientific literature analysis, qualitative expert interviews and quantitative survey lead to a better understanding of the role of social capital on entrepreneurship.

Social relations refer to social image of entrepreneurs. Experts believe that successful businessmen are related to a high status in the society, and their career is an attractive choice; however, the national culture of Lithuania does not encourage citizens to involve in entrepreneurial activities, does not facilitate the creativeness and innovative- 
ness. Therefore, there should be more attention paid to entrepreneurship at primary and secondary schools, colleges and universities.

The present research indicates concrete weaknesses of efficiency-driven companies, such as inexistent human resource strategies. A more intensive cooperation among such social players as universities, businesses and governments and establishment of formal process of generating and commercializing innovative ideas within organizations should draw attention of Lithuanian entrepreneurs. Building an innovative environment, thinking tools, reward system could help to generate new ideas, particularly when intrapreneurship levels (employees' entrepreneurship) are high. Finally, this paper reveals two consequences, triggered by not properly using the social capital potential: entrepreneurs' perception of innovativeness and competitiveness of their companies as being weak calls for stronger marketing efforts.

It should be remembered that social capital makes the influence via: assisting entrepreneurs in accessing resources, providing the feedback and accessing new information. All of these require a well-established information diffusion system and good social relations.

\section{References}

Acs, Z.; Autio, E. 2011. The Global Entrepreneurship and Development Index: a Brief Explanation, 1 March 2011 [online], [cited 10 May 2012]. Available from Internet: https://workspace. imperial.ac.uk/business-school/Public/research/I_Egroup/JC/GEDI\%20delegate\%20paper\%20 final\%20version.pdf

Acs, Z. J.; Szerb, L. 2010. The global entrepreneurship and development index (GEDI), in DRUID Conference, 16-18 June 2010, London, UK [online], [cited 10 May 2012]. Available from Internet: http://www2.druid.dk/conferences/viewpaper.php?id=502261\&cf=43

Adler, P.; Kwon, S.W. 2002. Social capital: the good, the bad and the ugly, in E. L. Lesser (Ed.). Knowledge and social capital: foundations and applications. Boston: Butterworth-Heinemann.

Cantner, U.; Stützer, M. 2010. The Use and Effect of Social Capital in New Venture Creation -Solo Entrepreneurs vs. New Venture Teams [online], [cited 10 May 2012]. Available from Internet: http://www.wiwi.uni-jena.de/Papers/jerp2010/wp_2010_012.pdf

Camps, S.; Marquès, P. 2011. Social Capital and Innovation: Exploring Intra-Organisational Differences [online], [cited 15 August 2012]. Available from Internet: http://www.uam.es/docencia/ degin/catedra/documentos/7_camps_marques.pdf

Colesca, S. E. 2009. Understanding trust in e-government, Engineering Economics (3): 7-15.

Coleman, J. S. 1988. Social capital in the creation of human capital, The American Journal of Sociology 94(Supplement): S95-S120. http://dx.doi.org/10.1086/228943

Dasgupta, P. 2009. A matter of trust: social capital and economic development, in Annual Bank Conference on Development Economics (ABCDE), 2009, Washington, US [online], [cited 18 May 2012]. Available from Internet: http://www.econ.cam.ac.uk/faculty/dasgupta/09/abcde09.pdf De Clercq, D.; Dakhli, M. 2004. Human capital, social capital, and innovation: a multi-country study, Entrepreneurship and Regional Development 16(2): 107-128.

http://dx.doi.org/10.1080/08985620410001677835

Doh, S.; Acs, Z. 2010. Innovation and social capital: a cross-country investigation, Industry and Innovation 17(3): 241-262. http://dx.doi.org/10.1080/13662711003790569 
Durlauf, S.; Fafchamps, M. 2005. Social capital, in P. Aghion, S. Durlauf (Eds.). Handbook of economic growth. Netherlands, Amsterdam: Elsevier.

Callois, J. M.; Schmitt, B. 2005. Measuring social capital for local economic development studies: the case of French rural areas, Working paper 2005 [online], [cited 18 June 2012]. Available from Internet: http://www2.dijon.inra.fr/cesaer/fichiers/pagesperso/schmitt/JMC_BS_WP_05_ SC-measure.pdf

Grootaert, C. 1998. Social capital: the missing link?, Social Capital Initiative Working Paper No. 3 [online], [cited 14 July 2012]. Available from Internet: http://siteresources.worldbank.org/INTSOCIALCAPITAL/Resources/Social-Capital-Initiative-Working-Paper-Series/SCI-WPS-03.pdf

Grootaert, C.; Van Bastelaer, T. 2002. Social capital: from definition to measurement, in S. Kahkonen, A. Krishna, E. Pantoja, C. Reid, S. F. Lawrence, E. Shrader (Eds.). Understanding and measuring social capital - a multidisciplinary tool for practitioners. US, Washington: The World Bank. http://dx.doi.org/10.1596/0-8213-5068-4

Hang, M.; Van Weezel, A. 2005. Media and entrepreneurship: a survey of the literature relating both concepts, in 18th Scandinavian Academy of Management Meeting (NFF), 18-20 August 2005 [online], [cited 18 May 2012]. Available from Internet: http://www.personal.psu.edu/ amh13/e-ship/hangandweezel.pdf

Harris, B. M. 2010. New venture entrepreneurship and its impact on globalization and economic development: Undergraduate Honors Thesis. Indiana University.

Hjerppe, R. 2003. Social Capital and Economic Growth Revisited [online], [cited 11 August]. Government institute for Economic Research. Available from Internet: http://www.vatt.fi/file/ vatt_publication_pdf/k307.pdf

Inkpen, A. C.; Tsang, E. W. K. 2005. Social capital, networks, and knowledge transfer, Academy of Management Review 30(1): 46-165. http://dx.doi.org/10.5465/AMR.2005.15281445

Yu, S.-H. 2013. Social capital, absorptive capability, and firm innovation, Technological Forecasting and Social Change 80(7): 1261-1270. http://dx.doi.org/10.1016/j.techfore.2012.12.005

Yusof, N. A.; Abidin, N. Z. 2011. Does organizational culture influence the innovativeness of public-listed housing developers?, American Journal of Applied Sciences 8(7): 724-735.

http://dx.doi.org/10.3844/ajassp.2011.724.735

Johnson, N.; Suarez, R.; Lundry, M. 2002. The importance of social capital in Columbian rural agroenterprises, in 25th International Conference of Agricultural Economists, 16-22 August 2002 [online], [cited 27 May 2012]. Available from Internet: http://ageconsearch.umn.edu/bitstream/25917/1/cp03jo01.pdf

Kaasa, A.; Parts, E. 2008. Human capital and social capital as interacting factors of economic development: evidence from Europe', Working Paper IAREG WP2/04 [online], [cited 20 May 2006]. Available from Internet: http://www.iareg.org/fileadmin/iareg/media/papers/WP2_04.pdf

Landry, L.; Amara, N.; Lamari, M. 2000. Does social capital determine innovation? Ro what extent?, in 4th International Conference on Technology Policy and Innovation, 28-31 August 2000, Curitiba, Brasil [online], [cited 27 May 2012]. Available from Internet: http://www.inovacijos. 1t/inopagalba/cms/114lt.pdf

Landry, R.; Amara, N.; Lamari, M. 2002. Does social capital determine innovation? To what extent?, Technological Forecasting and Social Change 69(7): 681-701.

http://dx.doi.org/10.1016/S0040-1625(01)00170-6

Laužikas, M.; Dailydaite, S. 2012. Benefits of social capital for sustainable innovation capabilities, Journal of Security Suitability Issues 2(3): 85-97.

Laužikas, M.; Vaiginienè, E.; Miliūtè, A.; Batulevičiūtè, S.; Dailydaitè, S.; Global Entrepreneurship Monitor. 2011. GEM Lithuania 2011 Report [online], [cited 15 February 2012]. Available from Internet: http://www.gemconsortium.org/docs/2779/gem-lithuania-2011-report 
Lee, S. H.; Wong, P.; Chong, C. 2005. Human and social capital explanations for R\&D outcomes, IEEE Transactions on Engineering Management 52(1): 59-68.

http://dx.doi.org/10.1109/TEM.2004.839955

Lin, N. 2000. Inequality in social capital, Contemporary Sociology 29(6): 785-795.

http://dx.doi.org/10.2307/2654086

Mačerinskienè, I.; Aleknavičiūtè, G. 2011. The evaluation of social capital benefits: enterprise level, Business, Management and Education 9(1): 109-126.

McKeever, E.; Anderson, A.; Jack, S .2014. Entrepreneurship and mutuality: social capital in processes and practices, Entrepreneurship and Regional Development 26(5-6): 453-477.

http://dx.doi.org/10.1080/08985626.2014.939536

Musai, M.; Abhari, M. F.; Fakhr, S. G. 2011. Effects of social capital on economic growth (international comparison), American Journal of Scientific Research No. 16 [online], [cited 6 July 2012]. Available from Internet: http://www.eurojournals.com/AJSR_16_14.pdf

Nahapiet, J.; Ghoshal, S. 1998. Social capital, intellectual capital, and the organizational advantage, Academy of Management Review 23(2): 242-266.

Nielsen, K. 2005. Social capital and innovation policy, Research Paper No. 10/03 [online], [cited 6 August 2012]. Available from Internet: http://www.google.lt/url?sa $=t \& r c t=j \& q=\& e s r c=s \& s o u r$ ce $=$ web $\&$ cd $=2 \& v e d=0 C G E Q F j A B \& u r l=h t t p \% 3 \mathrm{~A} \% 2 \mathrm{~F} \% 2$ Fciteseerx.ist.psu.edu $\% 2 \mathrm{Fviewdoc} \% 2$ Fdownload\%3Fdoi\%3D10.1.1.195.5121\%26rep\%3Drep1\%26type\%3Dpdf\&ei=Rj0tUMSnBOa P4gT99IDQDQ\&usg=AFQjCNEDkJCtJzmDxZ565_0iJThfmpyuKg\&sig2=n_OIfxBMyO821KOUagQVMA

Özdemir, A. A.; Demirci, A. E. 2012. Impact of social capital on radical innovation efforts of the organizations: a case in the aviation industry, Ege Academic Review 12(1): 55-68.

Pohja, T. L. 2009. Searching for the entrepreneur - the role of social norms among entrepreneurs, in 4th EDP Workshop, 2-3 April 2009, Spain, Barcelona [online], [cited 26 May 2012]. Available from Internet: http://webs2002.uab.es/edp/workshop09/Papers\%20Workshop/9Pohja.pdf

Porter, M. E. 2003. Building the Microeconomic Foundations of Prosperity: Findings from the Microeconomic Competitiveness Index [online], [cited 13 June 2012]. Available from Internet: http://www.isc.hbs.edu/pdf/GCR_0203_mci.pdf

Putnam, R. 1993a. Making democracy work. Civic traditions in modern Italy. Princeton: Princeton University Press.

Putnam, R. D. 1993b. The prosperous community: social capital and public life, The American Prospect 4(13): 35-42.

Serrat, O. 2011. A Primer on Intellectual Capital [online], [cited 17 May 2012]. Available from Internet: http://digitalcommons.ilr.cornell.edu/cgi/viewcontent.cgi?article=1108\&context=intl

Stam, W.; Elfring, T. 2008. Entrepreneurial orientation and new venture performance: the moderating role of intra- and extra-industry social capital, Academy of Management Journal 51 (1): 97-111. htp://dx.doi.org/10.5465/AMJ.2008.30744031

Uslaner, E. 1999. Trust but verify: social capital and moral behavior, Social Science Information 38 (1): 29-55. http://dx.doi.org/10.1177/053901899038001002

Übius, Ü.; Alas, R.; Elenurm, T. 2013. Impact of innovation climate on individual and organisational level factors in Asia and Europe, Journal of Business Economics and Management 14(1): 1-21. http://dx.doi.org/10.3846/16111699.2011.642081

Wennekers, S.; Stel, A.; Carree, M.; Thurik, R. 2009. The Relationship between Entrepreneurship and Economic Development: is it U-Shaped? [online], [cited 3 August 2012]. Available from Internet: http://www.ondernemerschap.nl/pdf-ez/H200824.pdf

Wong, P. K.; Ho, Y. P.; Autio, E. 2005. Entrepreneurship, innovation and economic growth: evidence from GEM data, Small Business Economics 24: 335-350.

http://dx.doi.org/10.1007/s11187-005-2000-1 


\section{APPENDIX 1}

\section{The publication-related APS questions and data}

Are there many, few, or no other businesses offering the same products/services to your customers?

\begin{tabular}{llcccc}
\hline & & Frequency & Percent & Valid Percent & Cumulative Percent \\
\hline Valid & $\begin{array}{l}\text { Many business } \\
\text { competitors }\end{array}$ & 86 & 4.3 & 52.8 & 52.8 \\
& $\begin{array}{l}\text { Few business } \\
\text { competitors }\end{array}$ & 56 & 2.8 & 34.4 & 87.1 \\
& $\begin{array}{l}\text { No business } \\
\text { competitors }\end{array}$ & 21 & 1.0 & 12.9 & 100.0 \\
& Total & 163 & 8.1 & 100.0 & \\
& Don't know & 2 & .1 & & \\
\hline Missing & System & 1838 & 91,8 & & \\
& Total & 1840 & 91,9 & & \\
\hline Total & & 2003 & 100,0 & & \\
\hline
\end{tabular}

Q1H2. Not counting owners, how many people will be working for this business five years from now?

\begin{tabular}{llcccc}
\hline & & Frequency & Percent & Valid Percent & Cumulative Percent \\
\hline Valid & 0 & 6 & .3 & 3.6 & 3.6 \\
& 1 & 9 & .4 & 5.5 & 9.1 \\
& 2 & 7 & .3 & 4.2 & 13.3 \\
& 3 & 19 & .9 & 11.5 & 24.8 \\
& $4-5$ & 18 & .9 & 10.9 & 35.8 \\
& $6-10$ & 30 & 1.5 & 18.2 & 53.9 \\
& $11-30$ & 27 & 1.3 & 16.4 & 70.3 \\
& 31 and more & 11 & .5 & 6.7 & 100.0 \\
& N/A & 38 & 1.9 & 23.0 & \\
& Total & 165 & 8.2 & 100.0 & \\
\hline Missing & System & 1838 & 91,8 & & \\
\hline Total & \multicolumn{5}{c}{100,0} \\
\hline
\end{tabular}


Q1G1. Will all, some, or none of your potential customers consider this product or service new and unfamiliar?

\begin{tabular}{llcccc}
\hline & & Frequency & Percent & Valid Percent & Cumulative Percent \\
\hline Valid & All & 28 & 1.4 & 17.8 & 17.8 \\
& Some & 43 & 2.1 & 27.4 & 45.2 \\
& None will consider this & & & & 100.0 \\
& new and unfamiliar & 86 & 4.3 & 54.8 & \\
& Total & 157 & 7.8 & 100.0 & \\
& Refused & 1 & .0 & & \\
& Don't know & 7 & .3 & & \\
\hline \multirow{2}{*}{ Missing } & System & 1838 & 91.8 & & \\
& Total & 1846 & 92.2 & & \\
\hline Total & & 2003 & 100.0 & & \\
\hline
\end{tabular}

Lithuanian entrepreneurs

\begin{tabular}{llcccc}
\hline & & Frequency & Percent & Valid Percent & Cumulative Percent \\
\hline Valid & Very bad & 63 & 3.1 & 3.1 & 3.1 \\
& 2 & 203 & 10.1 & 10.1 & 13.3 \\
& 3 & 1136 & 56.7 & 56.7 & 70.0 \\
& 458 & 22.9 & 22.9 & 92.9 \\
& Excellent & 143 & 7.1 & 7.1 & 100.0 \\
& Total & 2003 & 100.0 & 100.0 & \\
\hline
\end{tabular}

Innovative

\begin{tabular}{llcccc}
\hline & Frequency & Percent & Valid Percent & Cumulative Percent \\
\hline Valid & Absolutely disagree & 68 & 3.4 & 3.4 & 3.4 \\
& 2 & 212 & 10.6 & 10.6 & 14.0 \\
& 3 & 833 & 41.6 & 41.6 & 55.6 \\
& 4 & 646 & 32.3 & 32.3 & 87.8 \\
& Absolutely agree & 244 & 12.2 & 12.2 & 100.0 \\
& Total & 2003 & 100.0 & 100.0 & \\
\hline
\end{tabular}

Mindaugas LAUŽIKAS, Dr, is a Professor at ISC Paris Business School (Institut supérieur du commerce de Paris), Doctor of Economic Sciences, Leader of Global Entrepreneurship Monitor (Lithuania). Lecturing experience in such countries as Georgia, Sweden, France, Spain, Malta, Moldova and Lithuania is supported by publications in the field of knowledge economy, entrepreneurship and innovation. Research interests: national systems of innovation, entrepreneurship, knowledge diffusion, innovation and human resource strategies.

Simona DAILYDAITÉ is a Researcher in the fields of entrepreneurship and innovation, interested in social capital dimensions and media. Currently Simona successfully combines the career of researcher and business management. 